\title{
Estudo Geofísico do Potencial Hidrogeológico em Salinópolis, PA. Fase 2- Nascentes - Fonte do Caranã
}

\author{
Alves, J. G.V.; Carvalho, N. C. I. C.; Cunha, D. S.; Dias, A. V. M.; Magalhães, A. P. Jr.; UFPA - Campus Salinópolis \\ igvalves.geof@gmail.com, icaroo.cafange@gmail.com ; diego-s-cunha@hotmail.com ; aryella.valeska@gmail.com ; \\ alexjunior973@yahoo.com.br
}

\section{Copyright 2018, SBGf - Sociedade Brasileira de Geofísica}

Este texto foi preparado para a apresentação no VIII Simpósio Brasileiro de Geofísica, Salinópolis, 18 a 20 de setembro de 2018. Seu conteúdo foi revisado pelo Comitế Técnico do VIII SimBGf, mas não necessariamente representa a opinião da SBGf ou de seus associados. É proibida a reprodução total ou parcial deste material para propósitos comerciais sem prévia autorização da SBGf.

\section{Resumo}

Realiza-se em Salinópolis, PA, um estudo de avaliação do potencial hidrogeológico do pacote sedimentar terrígeno-carbonático das Formações Barreiras e Pirabas, com espessura média de 135 metros sobre o embasamento cristalino. Na Fase 1, identificou-se os principais aquíferos e sua continuidade lateral, através de correlação de perfis geofísicos dos poços perfurados para abastecimento de água na cidade: constatou-se a ocorrência de aquíferos extensos e de grandes espessuras, oferecendo grande vazão de água bicarbonatada-cálcica, na Fm. Pirabas, sotoposta ao embasamento cristalino. $\mathrm{Na}$ Fase 2, realiza-se a avaliação do potencial dos aquíferos superiores, inclusive o freático, que serve a muitos, através de poços abertos e nascentes, dando-se ênfase na investigação à famosa Fonte do Caranã - um símbolo da Cidade - onde é comum vê-se a população se abastecendo em seus vazadouros, cuja vazão, de comportamento sazonal, varia entre 800 e 5.000 litros/h. Essas nascentes localizam-se nas camadas arenosas da cobertura local constituída por sedimentos terrígenos da Formação Barreiras.

\section{Introdução}

O município de Salinópolis tem cerca de 45.000 habitantes. $\mathrm{Na}$ sede estão em torno de 25.000. O abastecimento público de água teve seu início no aproveitamento e estruturação da nascente Fonte do Caranã. Depois, a COSANPA implantou rede de distribuição a partir de várias áreas de captação por poços profundos. Mais recentemente, a Prefeitura do município assumiu o abastecimento em bairros novos (Fig.1).

O objetivo deste estudo é oferecer informações do potencial hidrogeológico local para contribuir com a gestão de águas subterrâneas na região. O projeto tem duas fases, A Fase 1 consiste em identificar aquíferos profundos de grande vazão, dentro da Formação Pirabas. $\mathrm{E}$, a Fase 2 consiste em avaliar o potencial hídrico da cobertura de sedimentos terrígenos, entendendo seu comportamento, volume explotável e qualidade da água.

\section{Metodologia/ Problema Investigado}

$\mathrm{Na}$ primeira fase, foram escolhidos 15 poços de diferentes Áreas de Captação da COSANPA, cujos perfis geofísicos foram digitalizados e reinterpretados para identificação dos aquíferos em cada poço. Depois foi realizada uma correlação poço a poço para avaliar a continuidade lateral dos aquíferos identificados.

$\mathrm{Na}$ Fase 2, identificou-se os pontos de nascentes afloramentos do aquífero livre - seu posicionamento, vazão, comportamento sazonal e qualidade da água, através de análise físico-química e bacteriológica. Perfis de poços e amostragem de sondagem na Fonte do Caranã foram usadas na proposta de seção do pacote que contém o aquífero livre (Fig.5).

\section{Resultados}

Como resultado da correlação dos perfis geofísicos dos poços, várias seções foram propostas, mostrando a continuidade lateral dos aquíferos, (Fig.3), com camadas permo-porosas de até 35 metros de espessura, indicando um enorme potencial hídrico subterrâneo.

Verificou-se que o afloramento do freático ocorre entre as cotas $12 \mathrm{~m}$ e $14 \mathrm{~m}$, gerando as nascentes (Fig.2). As medidas de vazão na fonte do Caranã definem o comportamento sazonal do aquífero freático, diretamente dependente da precipitação pluviométrica, que alcança uma vazão de $5.000 \mathrm{l} / \mathrm{h}$ no pico do período chuvoso, mas que devido sua extensão e volume ainda oferece vazão mínima de 800 litros por hora, durante o período de estiagem (Fig.4).

\section{Discussão e Conclusões}

Os aquíferos profundos da Formação Pirabas oferecem um potencial hídrico bastante promissor para o abastecimento público, instalação de indústrias e para a agricultura. $\mathrm{E}$, as nascentes, comprovadamente, oferecem água de qualidade mesmo na estiagem; mas há que se cuidar do saneamento para garantir sustentabilidade dessa fonte de água.

\section{Agradecimentos}

Os autores agradecem o apoio do Convênio 01/2014 FAPESPA-UFPA/Polo Salinópolis, que suporta as atividades da Fase 2 deste projeto.

\section{Referências}

Freimann,B.C., Alves, J. G. V.; Silva,M.W.C. 2014, Estudo Hidrogeológico através de perfis geofísicos de poços-Salinópolis/PA. Revista ABAS, v28, p14/21799784-30. 


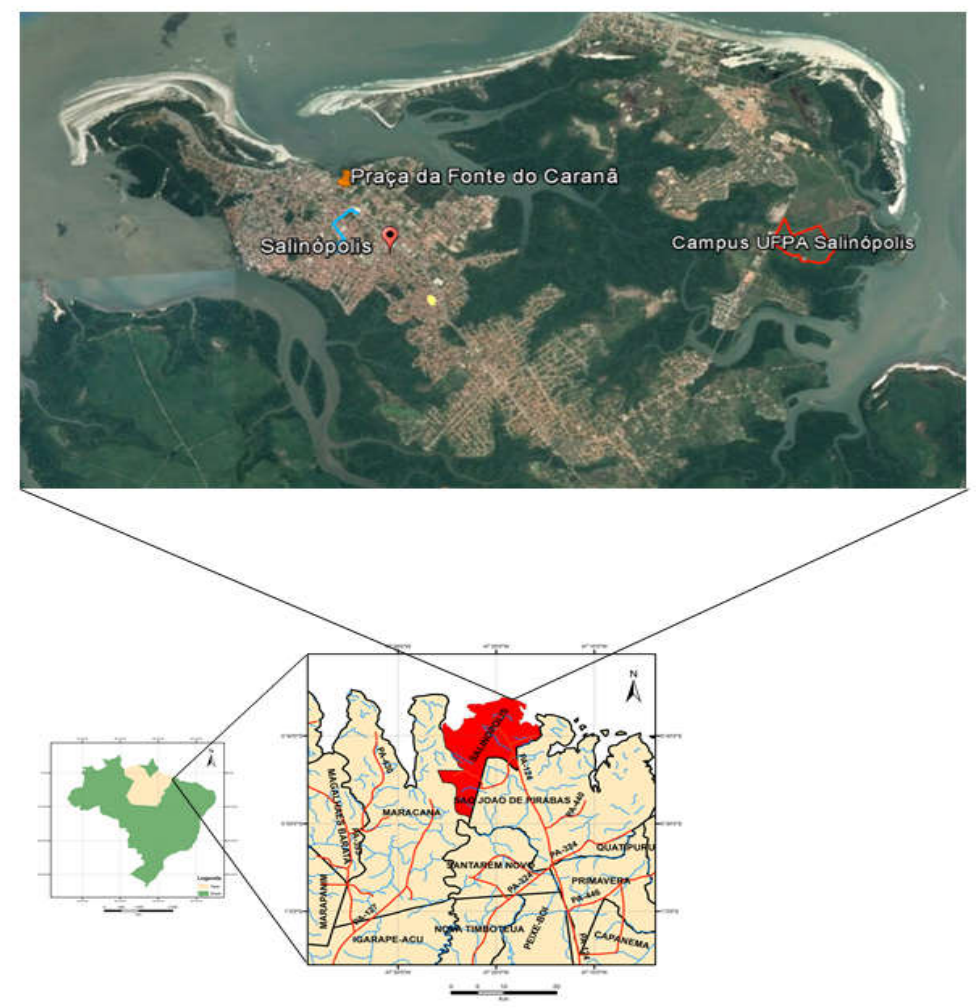

Figura 1 - Localização

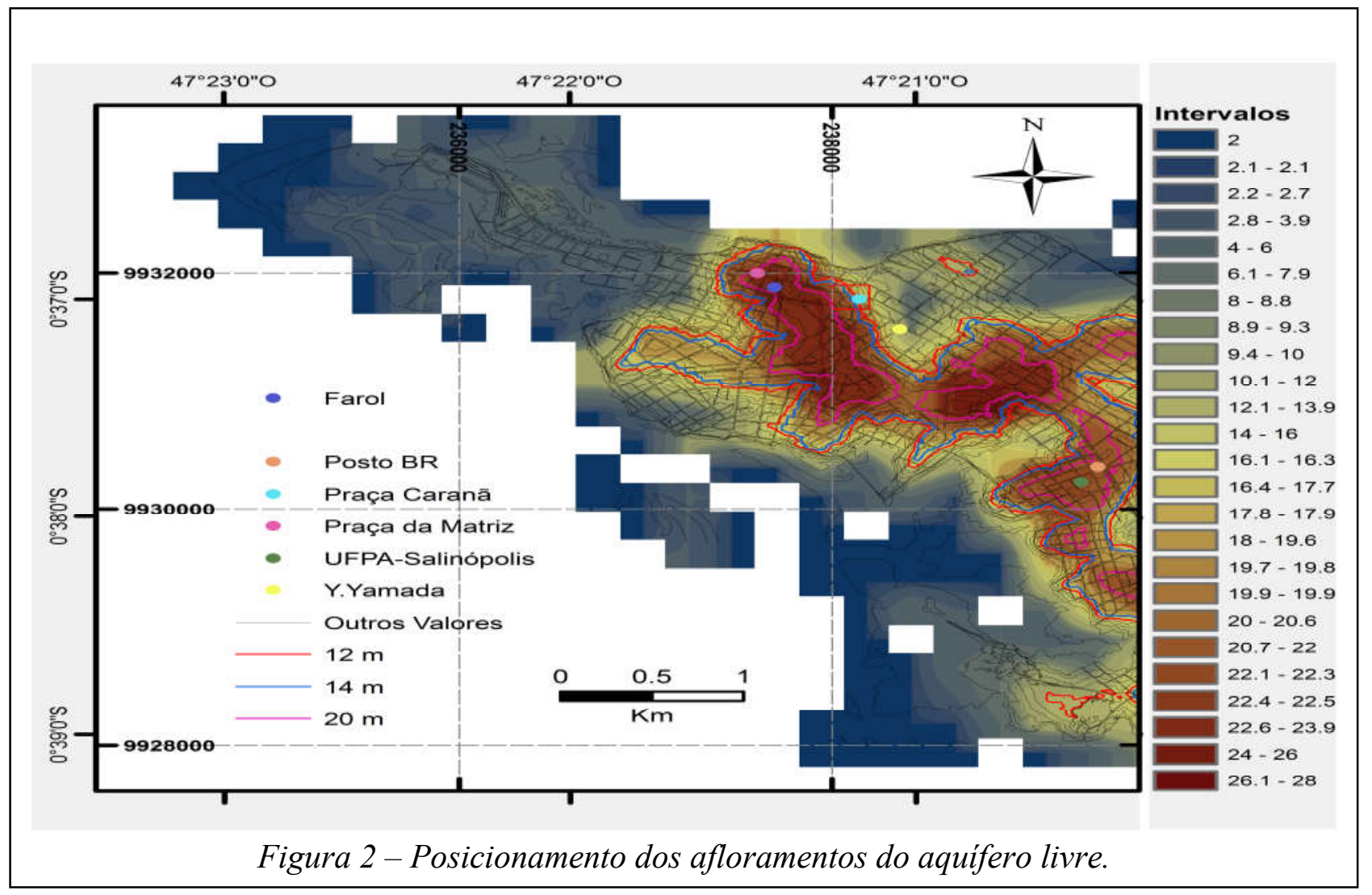




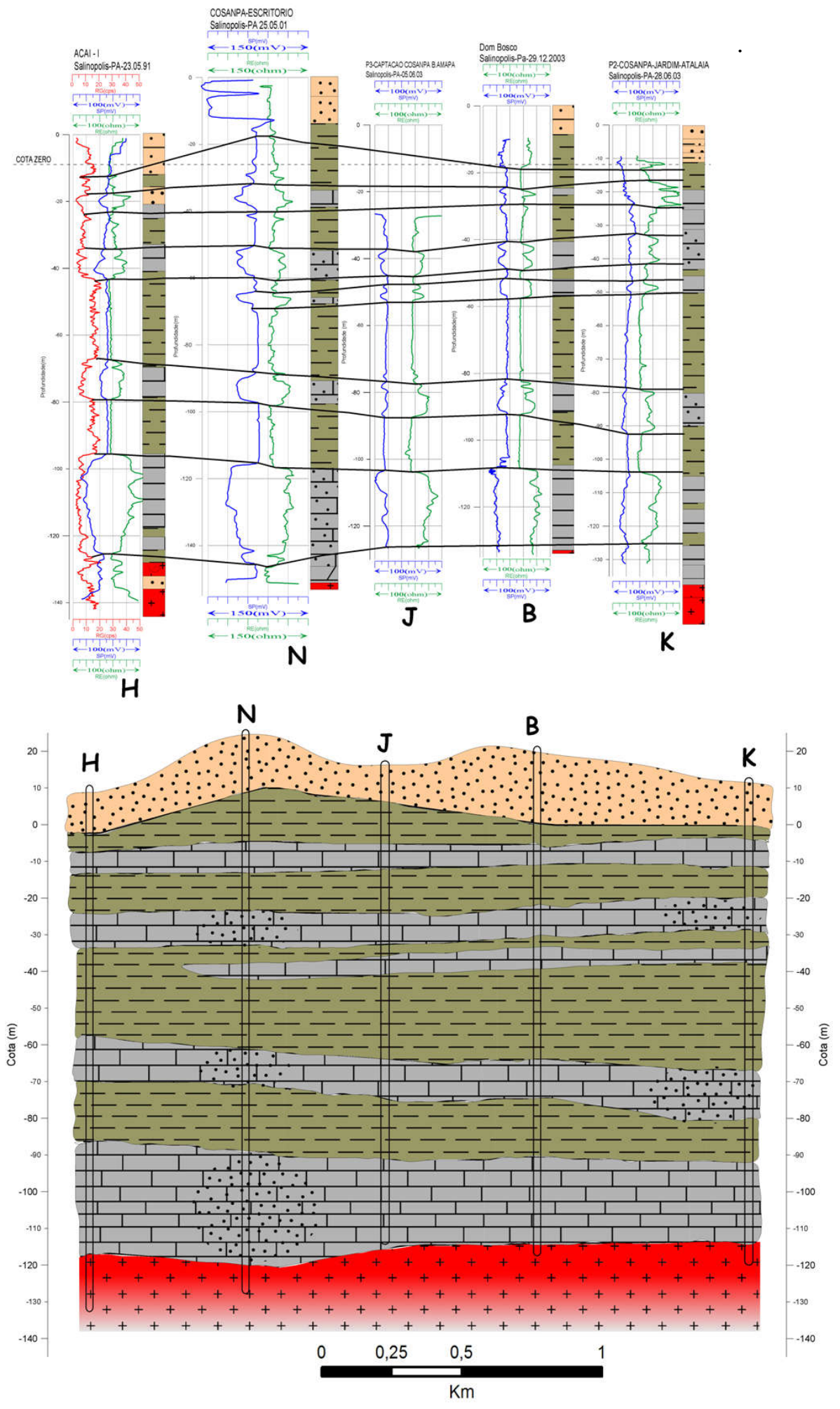

Figura 3 - Seção proposta como resultado da correlação, indicando as zonas permeáveis aquíferos - e sua continuidade lateral 


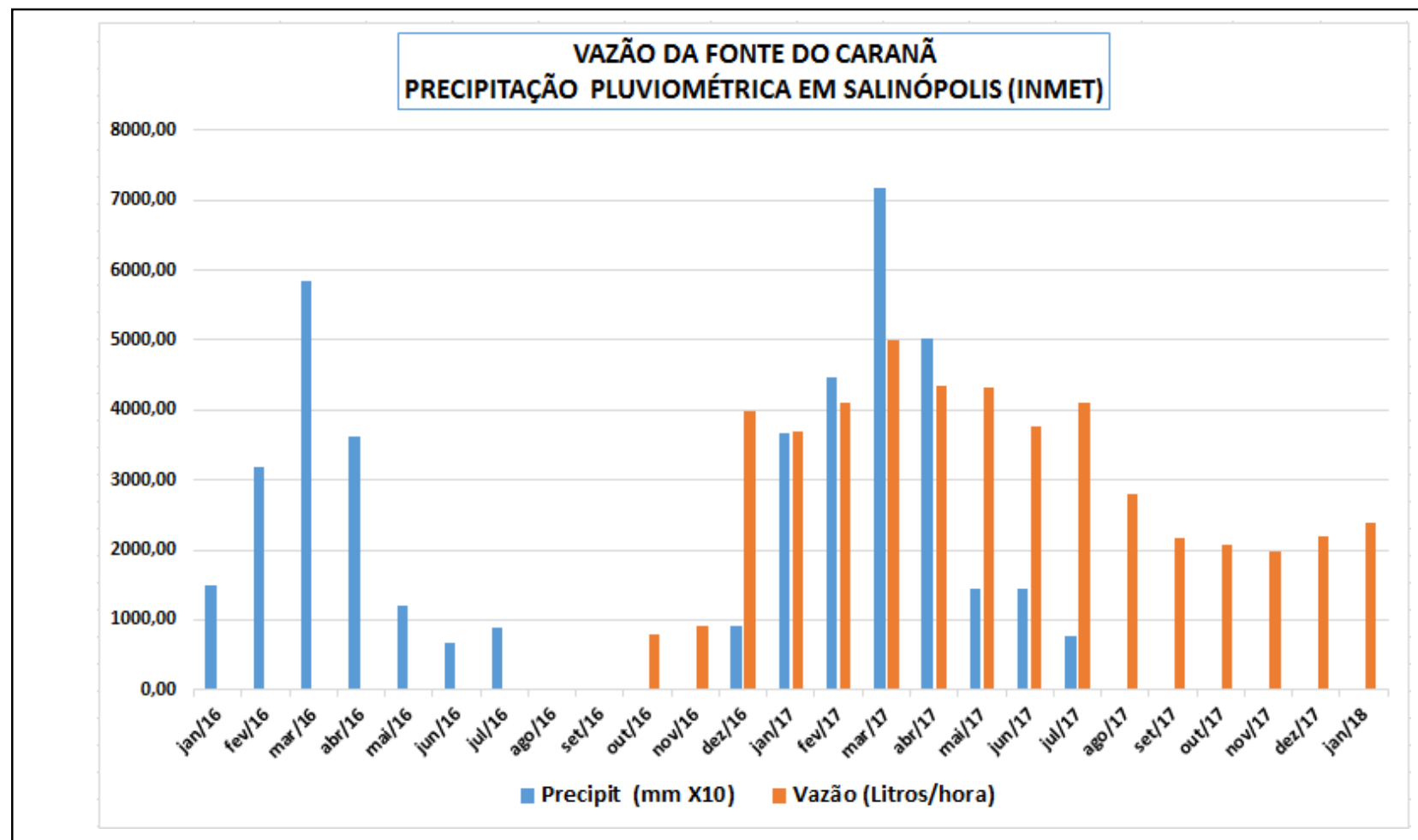

Figura 4 -Comportamento sazonal das nascentes, dependente da precipitação pluviométrica.

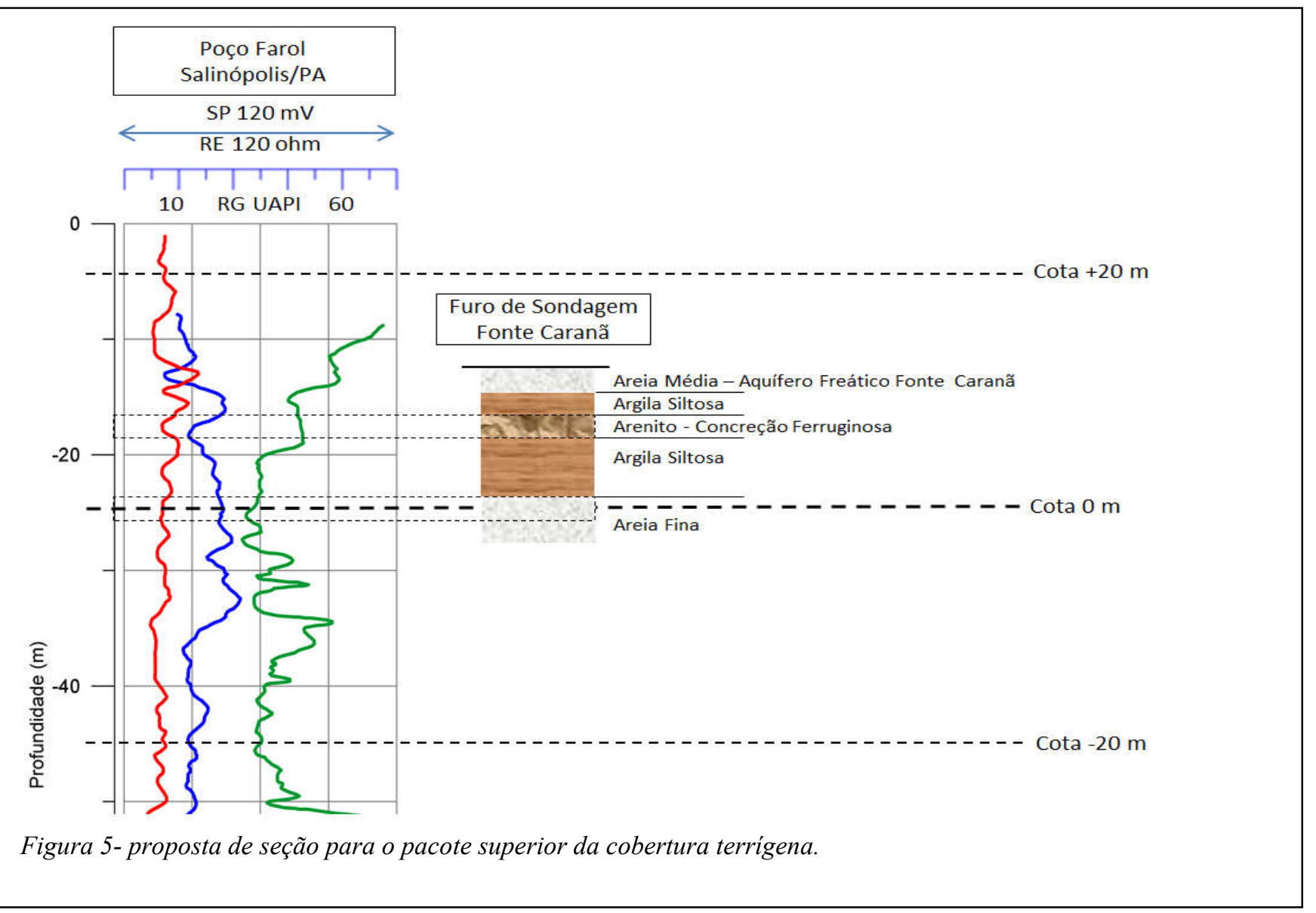

